\title{
Exploring the Use of Mobile Instant Messaging for Parent-Teacher Communication
}

\author{
https://doi.org/10.3991/ijim.v14i04.12403 \\ Azidah Abu Ziden ${ }^{(凶)}$ \\ Universiti Sains Malaysia, Penang, Malaysia \\ azidah@usm.my \\ Muhammad Faizal Abdul Rahman \\ Hospital Seberang Jaya, Penang, Malaysia \\ Too Woon Ching \\ Universiti Sains Malaysia, Penang, Malaysia
}

\begin{abstract}
Communication between teachers and parents is essential to foster parental involvement in school related activities. The purpose of this study is to evaluate the effectiveness of mobile instant messaging for parent-teacher communication in enhancing two-way communication between parents and teachers. In particular, the research examines the barriers on parental involvement and investigates the relationship between the use of mobile instant messaging for parent-teacher communication, as well as for families of different socio-economic and educational background. In addition, the study also evaluates parents' attitudes and perceptions towards the use of mobile instant messaging for communication with teachers. The respondents for this study were 251 parents with different background. This study employed a mix-method research design which involved quantitative and qualitative data. The findings revealed that time constraint is the primary reason for parents to be involved in school related activities. The study results also indicated that there is no relationship between family socio-economic background and the use of mobile instant messaging for parent-teacher communication. However, the findings show a significant relationship between parents' educational background and the use of mobile instant messaging for parents-teacher communication. Moreover, the study also found a receptive attitude among parents towards mobile based communications with teachers and school.
\end{abstract}

Keywords-Mobile instant messaging, parents-teacher communication, parents, teachers

\section{$1 \quad$ Introduction}

Technology has rapidly changing the educational environment and challenge not only teachers and students to adopt in teaching and learning, nonetheless confront parents to adapt accordingly. Parents involvement in schools' activities has become an 
increasing concern in the education environment for some time now especially in Malaysia. Parental involvement has been recognized as one of the most important variables influencing student academic achievement [21]; [24]; [33]. It is suggested that, for schools to meet higher academic standards for their students, a partnership must be established between the home (parents) and the school. Various studies have sought to discover the effects of computer-assisted technology applications on homeschool communication, e.g [8], [26] and [10]. Studies have also shown that using technology had indirectly improves communication of information, learning and instruction, student interest and motivation, and control of costs and resources [4].

Innovative technologies such as cell-phones, smartphones, e-mail and websites provide schools with new tools for reaching parents and keeping them informed about their children. Technology, in particular Internet-based communication technology, allows parents to overcome some of the barriers for lack of parents' involvement in schools [1]. According to [1] schools can use Internet-based parents-teacher communication to address time and schedule differences. It is suggested that by this study technology could serve to overcome the obstacles faced by parents as long as parents have access to the technology at home, work, library, or any other location. Many schools are turning to technology as a way to improve the communication with parents understanding that effective communication is the key to successful parentschool partnerships [19]. As society moves further into the $21^{\text {st }}$ Century, an increased dependency on technology is an evident. Technology has given parents and teachers the opportunity to explore new ways of communication. However, although mobile technologies are vital in facilitating parental involvement in schools, the cost involved in the technologies have led to a lack of cell phone used in school administration [11]. New technologies have the power to better the parent-teacher relationship by providing easy, efficient, and effective methods of transferring information [29].

\subsection{Parent-teacher communication in Malaysia}

In spite of the importance of parental involvement in their children's education and school activities, many parents especially in Malaysia do not seem to get involved in their children's education. Majority of parents place the responsibility to educate their children upon the teachers. They believe in the "leave it to the school" mentality. Furthermore, [14] found that in Malaysia, the major reason why students' examination results are poor is because lack of parents and family support, lack of supervision in the students' school activities, less guidance in students' homework and pass the hassle of assisting the children's homework to the elder siblings. It is depicted in this study that instant messaging would able to provide continuous communication for parents and teachers. Parent-teacher communication is crucial to assist parents to be proactively involved in their child's daily school progress.

[15] found that the most often reason for lack of parents' involvement was "parents' work schedules or other events prevented parents from participating" (p. 134). Moreover, numerous barriers to parent involvement exist for both parents and school personnel. Due to issues of time, distance, or convenience, many teachers and parents struggle to communicate with each other about student learning and classroom activi- 
ties. Consequently, communication initiated by teachers usually occurs only when the teacher faces problem or difficulties with a student. [3] found that teachers will find the time to communicate with parents of students that have academic or behaviour plan in place, but the rest of the parents are often not contacted and without a school wide plan to reach these parents, "schools may unintentionally isolate the students' parents" (p. 6). [15] discussed similar ideas in their study that parents tended to be reluctant to call schools, but would call "more often if their children were in trouble of failing their subjects" (p. 133).

\subsection{Parents involvement in schools}

[30] suggested that good communication between stakeholders helps dispel confusion about goals and procedures used to implement desired interventions. Research demonstrates the positive correlation between children's morale and motivation in school and positive parental involvement [34]; [6]. Parents perceive themselves as an integral part of the team when they are invited by the school, staff, teachers, and students to participate in the education process [6]. Parental involvement in school includes communicating between school and home, supporting learning at home, and participating in school life from helping in classrooms to decision making through governance structures [12]. Each one of these types of involvement play crucial part in building effective schools and improving student success. Effective parental involvement is believed to have a positive impact on a range of pupil-related outcomes [12]. Recent research has shown that a much broader range of parent involvement activities can influence positive school outcomes for children [18]. Furthermore, the research of [2] found a positive correlation between parental involvement and the academic success of students.

Research on the effects of parental involvement has revealed a reliable, positive relationship between parents' involvement in their children's education and student result [32]. [24] found that parental attendance at school meetings was especially productive. Additionally, the authors found that conducting family discussions, which focused on school related topics proved to have a positive impact on academic endeavours. One approach that suggested able to increase parents' involvement with schools might be the use of apps in mobile devices, emails and social media. Once parents/families experience ways smart phones can be used as a learning and connection tool they will become empowered and more open to using the devices as communication tools with the school [5]; [25].

[27] and [37] agree that technology can be beneficial in increasing parent-teacher communication as the first step to get parents involved in their child's education. Furthermore, they suggested the use of computer technology, such as the Internet and electronic mail or e-mail to foster lines of parent-teacher communication. It is clearly show that parents' involvement is essential in their children education success and parent-teacher communication need to be improved in Malaysia. Communication has been identified as a key to increasing parents' involvement [16]; [22]. Technology has been shown to increase the means by which parents and teachers communicate [8]; [17]. Therefore, this study was conducted to determine the effectiveness of using 
mobile instant messaging for parent-teacher communication in improving parents' involvement in schools' related activities. Parent-teacher communication is this study refers to two-way, meaningful, clear and ongoing process by which information is exchanged between school (teachers, administrators, counsellors) and home (parents/guardians) as it pertains to academics and school activities.

\section{Research Objectives}

This study focused on the effectiveness of mobile instant messaging communication between teachers and parents. This study intends to meet the following objectives:

To explore the barriers that hinder parental involvement in parent-teacher communication.

- To investigate the relationship between family socio economic background and the use of mobile instant messaging for parents-teacher communication.

- To investigate the relationship between parents' educational background and the use of mobile instant messaging for parents-teacher communication.

To study parents' attitudes and perceptions towards the use of mobile instant messaging for parents-teacher communication.

This paper addresses two hypotheses, which are:

- Ho1: There is no significant relationship between family socio-economic background and the use of mobile instant messaging for parents-teacher communication.

- Ho2: There is no significant relationship between parents' educational background and the use of Mobile instant messaging parents-teacher communication.

This paper highlighted opportunities to increase home participation in school activities, through the use of technology as communication tools, parents may be able to participate in a more inclusive, participatory educational environment. The study will also make a significant contribution to educational leadership because it will address how emerging mobile technology assists in increasing parents' involvement in school. In addition, this study may also help in improving the awareness of the public about the importance of parents' involvement in their children education. The increment of parents' involvement would be able to assists in terms of academic achievement, therefore educational leaders may benefit from finding ways to increase parents' involvement.

\section{Research Methods}

This study was conducted using mixed-method approach that combines both quantitative and qualitative approaches. In this study, the close-ended survey questions 
comprised the quantitative data was used while the interview questions provided the qualitative data. For the purposes of this study, survey research, also known as descriptive research is used. The population of this study are parents of a primary school in Penang, Malaysia. The sample of this study are parents whom their children are at different grade levels from Year 1 to Year 6. A random sampling technique was used to select the sample. The sample consists of 251 parents who are from different socioeconomic and academic background.

A set of questionnaires was developed based on the problem statement and a review of the literature. This instrument was used to gather descriptive data regarding barriers to parents' involvement, parents' use of mobile instant messaging for parentsteacher communication and their perception towards the use of mobile instant messaging as well as demographic information. The questionnaire was divided into four sections, consisting of 28 items. Section A of the instrument established demographic information such as gender, age, level of education, and monthly household income. Section B of the survey utilized a Likert-like frequency items format on an interval scale consisting of strongly disagree, disagree, agree and strongly agree to determine the barriers to why parents do not get involved in their child's education. The items in section $\mathrm{C}$ also used Likert-like frequency that dealt with the parents' experience in using mobile instant messaging for parents-teacher communication. Finally, the items in section D of the survey contains with questions regarding parents' attitudes and perception towards using mobile instant messaging for parents-teacher communication. Table 1 shows the structure of the questionnaire.

Table 1. Structure of Questionnaire

\begin{tabular}{|l|l|c|}
\hline Section & \multicolumn{1}{|c|}{ Variables } & Number of Items \\
\hline Section A & Demographic Information & 4 \\
\hline Section B & Barriers to parental involvement & 6 \\
\hline Section C & The use of mobile instant messaging for parents-teacher communication & 10 \\
\hline Section D & Perceptions toward the use of instant messaging & 8 \\
\hline & Total & $\mathbf{2 8}$ \\
\hline
\end{tabular}

The second aspect of this study was qualitative in nature. Interviews were conducted with the parents to augment the findings from the surveys as well as to obtain valuable insights into parental involvement and communication. The interviews were semi-structured and focused on the barriers that hinder parental involvement and parents' attitudes and perspective towards using mobile instant messaging for parentteacher communication. The interview served as an opportunity for the participants to express their impressions fully and provide a more in-depth view of the topics discussed such as their perceptions of the method used in school for parents-teacher communication. All interviews were recorded, analysed and coded promptly. Moreover, the purpose of this interview was also to further analyse significant perspective of parents towards the use of technology for parents-teacher communication which is in line with the third research objective. This analysis included coding transcripts, carefully reading and re-reading of all data by the researcher, and noting recurring themes; all of these are techniques used in qualitative research to help ensure trustworthiness. 
The use of multiple sources of evidence in this study allowed for data triangulation. Triangulation, the "cross-validation among data sources and data collection strategies" [31], provides a means for corroborating the same factor phenomenon. The convergence of data upon a specific fact provided validity within the study.

\subsection{Data collection and analysis}

The survey forms were distributed to the parents of 300 students in grades 1 to 6 . Of the 300 survey, 251 were returned, for a response rate of $83.67 \%$. Respondents had the option of skipping answering questions, which they were not comfortable with. $42.2 \%$ of the respondents are male while $57.8 \%$ are female. Respondents of the survey were primarily between age of 36 to $46(69.4 \%)$. However, the parents who are under age of 35 comprised $12.7 \%$ of the respondents. Additionally, $15.1 \%$ of the parents in the population are ranged from the age of 46 to 50 while only $2.8 \%$ of the parents are above 51 years old. With regards to the parents' highest level of education, the survey findings indicated that almost half of the parents are highly educated. $77.8 \%$ of the respondents are diploma holders or holding a higher level of education. Out of the 251 respondents, only $4.4 \%$ of the respondents attended primary school and $17.9 \%$ attended secondary school. For the socioeconomically disadvantaged students where their monthly household income is below RM1K comprised $5.6 \%$ of the school. However, there were $15.1 \%$ of the respondents indicated that they have a household income of RM9k or above.

To investigate the effectiveness of mobile instant messaging between parents and teachers as a key part of parental involvement, barriers in involvement needed to be identified. Therefore, the first question driving this study was "What are the barriers that hinder parental involvement?" In order to address this inquiry and to work towards overcoming the obstacles impacting parental involvement at the study school, the study had explored the barriers that hinder most parents from involving in their children's education. Previous researchers have identified a few barriers that prohibit parents from being involved in their children's education, including having work commitments, not knowing how to help their child, or not feeling welcomed at the school [9]. Survey questions were used to determine the barriers to parental involvement that most parents were facing at the school. Parents were given a range of response options ( $1=$ Strongly disagree; $2=$ Disagree; $3=$ Agree; $4=$ Strong agree $)$ to identify their perceptions of the barriers on their involvement in school activities.

Table 2 shows the frequency results of each barrier. The results indicated that the most significant barrier to parental involvement was not having time due to work or family needs. Out of 251 parents who responded to the survey, $39.9 \%$ of the parents either strongly agree or agree that lack of time was a barrier for them to be involved in school related activities. $23.1 \%$ of the parents do not know how to help their children. The findings show that $27.5 \%$ of parents felt that it is the school's job to educate their child. In regard to the responses in item 4 and 5, only $10.4 \%$ of the parents were not comfortable talking to the teacher where as $11.2 \%$ of the parents do not feel welcomed at school. The results indicated that $22.3 \%$ of parents do not know how to get involved in their children's education. 
Table 2. Barriers to Parental Involvement $(\mathrm{N}=251)$

\begin{tabular}{|c|c|c|c|}
\hline Item & & Frequency $(\mathbf{N})$ & Percent $(\%)$ \\
\hline \multirow[t]{4}{*}{ Do not have time due to work or family needs } & Strongly disagree & 36 & 14.3 \\
\hline & Disagree & 115 & 45.8 \\
\hline & Agree & 79 & 31.5 \\
\hline & Strongly agree & 21 & 8.4 \\
\hline \multirow[t]{4}{*}{ Do not know how to help } & Strongly disagree & 54 & 21.5 \\
\hline & Disagree & 139 & 55.4 \\
\hline & Agree & 47 & 18.7 \\
\hline & Strongly agree & 11 & 4.4 \\
\hline \multirow[t]{4}{*}{ It is the school's job to educate the child } & Strongly disagree & 67 & 26.7 \\
\hline & Disagree & 115 & 45.8 \\
\hline & Agree & 62 & 24.7 \\
\hline & Strongly agree & 7 & 2.8 \\
\hline \multirow[t]{4}{*}{ Feel not comfortable talking to the teacher } & Strongly disagree & 69 & 27.5 \\
\hline & Disagree & 156 & 62.2 \\
\hline & Agree & 24 & 9.6 \\
\hline & Strongly agree & 2 & 0.8 \\
\hline \multirow[t]{4}{*}{ Do not feel welcomed at the school } & Strongly disagree & 67 & 26.7 \\
\hline & Disagree & 156 & 62.2 \\
\hline & Agree & 23 & 9.2 \\
\hline & Strongly agree & 5 & 2.0 \\
\hline \multirow[t]{4}{*}{ Do not know how to get involved } & Strongly disagree & 58 & 23.1 \\
\hline & Disagree & 137 & 24.6 \\
\hline & Agree & 48 & 19.1 \\
\hline & Strongly agree & 8 & 3.2 \\
\hline
\end{tabular}

Section $\mathrm{C}$ of the survey questions measure the connection between family socioeconomic background and parents' educational background and the use of mobile instant messaging for parent-teacher communication. To determine whether technology could be used to promote parent involvement, parents were asked the frequency they access to any mobile devices with Internet connection at home or at work. Out of all respondents, only $4.8 \%$ did not have access to a mobile device with Internet access and $2.4 \%$ rarely access to a mobile device with Internet access. Data indicated that $50.2 \%$ of the respondents always access to a mobile device with Internet connection during work or at home. $25.9 \%$ responded frequently while $16.7 \%$ responded occasionally.

The result of the data analysis for testing the two hypotheses in terms of Pearson Correlation Coefficient obtained are as shown in Table 3 and Table 4. 
Table 3. Pearson Correlation for monthly household income and the use of mobile instant messaging for parents-teacher Communication

\begin{tabular}{|l|l|c|c|}
\hline \multicolumn{2}{|l|}{} & $\begin{array}{c}\text { Monthly household } \\
\text { income }\end{array}$ & $\begin{array}{c}\text { The Use of Mobile Instant } \\
\text { Messaging for Parent- } \\
\text { teacher Communication }\end{array}$ \\
\hline \multirow{3}{*}{ Monthly household income } & Pearson Correlation & 1 & .061 \\
\cline { 2 - 4 } & Sig. (2-tailed) & & .334 \\
\cline { 2 - 4 } & $\mathrm{N}$ & 251 & 251 \\
\hline \multirow{2}{*}{$\begin{array}{l}\text { The Use of Mobile instant } \\
\text { messaging for parent-teacher } \\
\text { communication }\end{array}$} & Pearson Correlation & .061 & 1 \\
\cline { 2 - 4 } & Sig. (2-tailed) & .334 & 251 \\
\cline { 2 - 4 } & $\mathrm{N}$ & 251 & \\
\hline
\end{tabular}

Table 4. Pearson Correlation for Higher Level of Education and The Use of mobile instant messaging for parent-teacher Communication

\begin{tabular}{|l|l|c|c|}
\hline \multicolumn{2}{|l|}{} & $\begin{array}{c}\text { Highest level of } \\
\text { education }\end{array}$ & $\begin{array}{c}\text { The Use of Mobile Instant } \\
\text { Messaging for Teacher- } \\
\text { Parent Communication }\end{array}$ \\
\hline \multirow{3}{*}{ Highest level of education } & Pearson Correlation & 1 & $.134^{*}$ \\
\cline { 2 - 4 } & Sig. (2-tailed) & & .033 \\
\cline { 2 - 4 } & $\mathrm{N}$ & 251 & 251 \\
\hline \multirow{2}{*}{$\begin{array}{l}\text { The Use of mobile instant } \\
\text { messaging for parent-teacher } \\
\text { Communication }\end{array}$} & Pearson Correlation & $.134^{*}$ & 1 \\
\cline { 2 - 4 } & Sig. (2-tailed) & .033 & 251 \\
\cline { 2 - 4 } & $\mathrm{N}$ & 251 & \\
\hline \multirow{2}{*}{$*$. Correlation is significant at the 0.05 level (2-tailed) } & & \\
\hline
\end{tabular}

H01 in this study proposed that there is no significant relationship between family socio-economic background and the use of mobile instant messaging for parentteacher communication. The result of Pearson Correlation Coefficient shows that $r$ $(251)=0.06, p>0.05$. This indicates that there is no significant relationship between family socio-economic background and the use of mobile instant messaging for parent-teacher communication. Therefore, this hypothesis is accepted.

Consequently, $\mathrm{H}_{0} 2$ proposed that there is no significant relationship between parents' educational background and the use of mobile instant messaging for parentteacher communication. Result of Pearson Correlation Coefficient shows that $\mathrm{r}$ (251) $=0.13, \mathrm{p}<0.05, \mathrm{r}^{2}=0.02$. The correlation is significant at the 0.05 level (2-tailed). It shows that there is a significant positive relationship between family socio-economic background and the use of mobile instant messaging for parents-teacher communication. Coefficient of determination shows that $2 \%$ from variance in the use of mobile instant messaging for school-home communication is explained by parents' educational background. Hence, the null hypothesis is rejected. $\mathrm{H}_{0} 2$ is rejected because the results indicated that there is a significant and positive relationship between parents' educational background and the use of mobile instant messaging supported parentteacher communication.

In order to promote parent's use of mobile technology to communicate with school, it was imperative to determine what are the conditions that enable parents to be involved in parent-teacher communication. To investigate parents' perceptions and 
attitudes of the effectiveness parent-teacher communication through the use of mobile devices, it is important to determine parents' perceived usefulness and perceived ease of use as well as their perceptions of their own experience of using the technology.

Table 5. Perceptions towards the use of mobile instant messaging

\begin{tabular}{|c|c|c|c|}
\hline Item & & Frequency $(\mathbf{N})$ & Percent (\%) \\
\hline \multirow{4}{*}{$\begin{array}{l}\text { I feel that mobile instant messaging is a useful tool in } \\
\text { increasing parental involvement }\end{array}$} & Strongly disagree & 2 & 0.8 \\
\hline & Disagree & 21 & 8.4 \\
\hline & Agree & 154 & 61.4 \\
\hline & Strongly agree & 74 & 29.5 \\
\hline \multirow{4}{*}{$\begin{array}{l}\text { I feel that electronic forms of communication (email, } \\
\text { web site, parent portal) are convenient to use }\end{array}$} & Strongly disagree & 4 & 1.6 \\
\hline & \begin{tabular}{|l|} 
Disagree \\
\end{tabular} & 21 & 8.4 \\
\hline & \begin{tabular}{|l|} 
Agree \\
\end{tabular} & 152 & 60.5 \\
\hline & Strongly agree & 74 & 29.5 \\
\hline \multirow{4}{*}{$\begin{array}{l}\text { I feel more comfortable using mobile instant messaging } \\
\text { to communicate with the school }\end{array}$} & Strongly disagree & 6 & 2.4 \\
\hline & \begin{tabular}{|l|} 
Disagree \\
\end{tabular} & 68 & 27.1 \\
\hline & \begin{tabular}{|l|} 
Agree \\
\end{tabular} & 145 & 57.8 \\
\hline & \begin{tabular}{|l|} 
Strongly agree \\
\end{tabular} & 32 & 12.7 \\
\hline \multirow{4}{*}{$\begin{array}{l}\text { I trust the privacy and confidentiality of mobile instant } \\
\text { messaging communications with the school }\end{array}$} & Strongly disagree & 4 & 1.6 \\
\hline & Disagree & 71 & 28.3 \\
\hline & Agree & 154 & 61.4 \\
\hline & Strongly agree & 22 & 8.8 \\
\hline \multirow{4}{*}{$\begin{array}{l}\text { I get more information from mobile instant messaging } \\
\text { about my child than in parent-teacher conferences }\end{array}$} & Strongly disagree & 22 & 8.8 \\
\hline & \begin{tabular}{|l|} 
Disagree \\
\end{tabular} & 107 & 42.6 \\
\hline & Agree & 105 & 41.8 \\
\hline & Strongly agree & 17 & 6.8 \\
\hline \multirow{4}{*}{$\begin{array}{l}\text { Teachers are more accessible via mobile instant messag- } \\
\text { ing than they are for personal visits }\end{array}$} & Strongly disagree & 24 & 9.6 \\
\hline & Disagree & 98 & 39.0 \\
\hline & Agree & 104 & 41.4 \\
\hline & Strongly agree & 25 & 10.0 \\
\hline \multirow{4}{*}{$\begin{array}{l}\text { It is important to me that school provides means for } \\
\text { communicating with parents through the use of mobile } \\
\text { instant messaging }\end{array}$} & Strongly disagree & 6 & 2.4 \\
\hline & \begin{tabular}{|l|} 
Disagree \\
\end{tabular} & 30 & 12.0 \\
\hline & \begin{tabular}{|l|} 
Agree \\
\end{tabular} & 159 & 63.3 \\
\hline & Strongly agree & 56 & 22.3 \\
\hline \multirow{4}{*}{$\begin{array}{l}\text { I am satisfied with the current level of communication } \\
\text { with the school through the use of mobile instant mes- } \\
\text { saging }\end{array}$} & Strongly disagree & 24 & 9.6 \\
\hline & Disagree & 107 & 42.6 \\
\hline & \begin{tabular}{|l|} 
Agree \\
\end{tabular} & 108 & 43.0 \\
\hline & Strongly agree & 12 & 4.8 \\
\hline
\end{tabular}

Two interviews with two parents (Parent A and Parent B) were also conducted to provide a deeper understanding of the questions arose in the study. Parents were asked a few questions regarding the barriers they faced in their involvement in children's education as well as their perception of using technology for communications in school. The researcher transcribed and coded the data. After transcribing and reading through the data, the researcher chunked the data into smaller meaning parts. Once all the data were coded and grouped, 2 themes emerged: barriers to parental involvement and the use of technology for communication. 
In regards to barriers, parents were asked "Do you think there is any barrier to parent involvement in schools?" and "Which do you think is the greatest barrier that most parents are facing?" Parent A stated that he did not think that there neither barrier for parent's involvement nor factors that hinder other parents to get involved. However, Parent B stated that busy schedules are the greatest barrier. She commented that her kids were involved in many after-school activities and she was always work and get home late. Parent A was found to be more proactive in involvement either in his child's educations or school activities. However, Parent B said that "I have to work to support my family, I have no time to help my child especially when it comes to in school activities. So, I send him to school for teacher to educate him, after school I send him to Edu Care Centre so that the teacher there could help me to monitor his homework."

After identifying the barriers that hinder parental involvement, the parents were asked "Do you think access to mobile technology plays an important role in parent involvement in schools? Why?" Parent A said that it is very important as it promote parent remote support to school. Parents do not need to come to school physically. Besides that, parent A always use WhatsApp application to communicate with his child's teacher. He checked school Facebook frequently for information and updates about the school. When Parent A was asked "Do you have any suggestion of a suitable way for improving parents' involvement?" He suggested parents' involvement could be increased through school charity program, such as during school canteen day, mini marathon, and communal work. School should encourage parents come to help in these events, and hence promote a better relationship between parents and teachers and create better parent-teacher communication.

Parent B also agreed that mobile technology is a useful tool in increasing parents' involvement especially for parents who are working and have no time to visit the school or teachers. She liked having access to school websites and being able to text or email teachers because she is busy and like to be able to get information quickly or at a convenient time. She felt that she could get more information from mobile communications about her child than in parent-teacher conferences as during the conferences, too many parents wanted to meet the teacher, she might not have quality communication with teacher about her child. Besides that, she also suggested that school should always update the websites with current information and she hoped that teacher could contact her more frequent to communicate about her child in school.

\section{$4 \quad$ Findings and Discussion}

The results of the study show that the parents in this study have positive perception and attitude towards the use of mobile technology particularly mobile instant messaging as a tool for communicating with school. However, more than half of the parents were not fully satisfied with the current level of communication with school through the use of mobile technology. From the qualitative data, the parents would like teacher to use mobile instant messaging such as WhatsApp or Telegram with much more frequent to communicate updates and information about the class and school activi- 
ties. They also suggested that the school website is updated with current information. It was important to gain an understanding of why there has been a decline in parents' involvement in schools related activities. To better understand the the issues parents were facing in terms of parent-teacher communication, types of parents' involvement in school related activities need to be established by schools with the parents. According to previous researches, there are some common barriers that prohibit parents from being involved in their children's education including lack of time, not feeling welcomed at the school, not knowing how to help their child, and perceptions of parents to educate the child [9]. Furthermore, the information shared by the parents in the interviews proved most valuable in determining the types of obstacles that most families were coping with. The parents interviewed in the study also agreed that lack of time or inflexible work schedules was the greatest obstacles that hinder parents from getting involvement. Most parents nowadays are career working parents have work commitments and unable to spend much time in helping their children's especially in relation to school activities. Even those parents who have manageable work schedules often have other responsibilities and commitments. There is not enough time to devote to every child especially in families with more than one child.

Some parents have the desire to spend time to get involved or understand better about their children's studies, however they are not able to participate because they feel that as children have been at school all day and attending extra classes or activities after school, they need time to rest, especially within Malaysia context. Besides, almost a quarter of the parents feel that it is the school's job to educate the child. They placed the responsibility to educate their children upon the teachers. It is seen as it is the responsibility of the school and the teachers to educate their children during the hours that their children are at school and with some it will be difficult to change this deeply engrained assumption. According to [14], technology can influence parents' practices with regard to communicate with teachers. The widespread use of technology has restructured social relationship and the purpose of communicating with others [28]; [35]; [36]. Newer mobile technologies provide opportunities to communicate faster, create new social practices, and new patterns of communication [20]; [23], and helps people to stay connected. Technology-based communication tools are designed to make the communication faster, flexible, easier and convenient. Besides that, it reduces the need for travelling to and from the school when time is of the essence. It also allows the information about students to transfer quickly, allowing for decision to be made faster in certain situation.

\section{Conclusion}

The findings of this study indicated that lack of time appears to be the greatest barriers to parents' involvement in schools related activities. Exploring instant mobile messaging tools as an avenue for increasing parental involvement in the academic setting is of critical importance. By doing so has strong implications for creating new social practices and new patterns of mobile communication between parents and teachers. This study was significant because the results revealed the potential for mo- 
bile instant messaging to be used to improve parent-teacher communication. Based on the finding of this study, parents are receptive to mobile instant messaging as a tool to communicate with teachers and school. Additionally, communication through these modes offers the opportunities to conduct two-way conversations and can provide interactive opportunities between parents and teachers. This study showed that technology can conveniently be applies to research based best practices for increasing parents' involvement. This study investigated the effectiveness of mobile instant messaging for parent-teacher communication in improving parental involvement at one of the primary school in Penang. While this study focused on a small window of opportunity at one school in Penang, the findings promise for the use of mobile technology as an effective tool for establishing better lines of communication between parents and teachers as well as encouraging higher levels of parents' involvement in their children school activities. However, it is important to highlight that there is no one particular plan that will work for every school since the obstacles of parents' involvement vary from school to school and parents to parents. However, this study did reveal the vast possibilities of utilizing mobile technology to build better partnerships between the parents and the teachers. Future studies could include studies focusing on parental preferences of specific types of electronic communications and an investigation focusing on the skills and training teachers need in order to facilitate stronger partnerships with parents.

\section{References}

[1] Abdal-Haqq, I. (Ed). (2002). Connecting schools and community through technology. Alexandria, VA: National School Boards Association.

[2] Anderson, K.J., \& Minke, K.M. (2007). Parent Involvement in Education: Toward an Understanding of Parents' Decision-making. Journal of Educational Research, 100, 311-323. https://doi.org/10.3200/joer.100.5.311-323

[3] Blackerby, J. M., Jr. (2005). Effective communication: Opening lines of communication with email (Master's thesis, Valdosta State University, Valdosta, GA).

[4] Blanchard, J. \& Oliver, J. (1999). The family-school connection: Possibilities for technology. Computers in Schools, 15(1), 65-72. https://doi.org/10.1300/j025v15n01_10

[5] Branzburg, J. (2001). Talking to parents online. Technology and Learning, 21(9), 54.

[6] Burton, K. (2015). Parent Perceptions of Their Involvement in and the Effectiveness of an Integrated Social Skills Program.

[7] Chindanya, A. (2011). Parental involvement in primary schools: a case study of the Zaka district of Zimbabwe (Doctoral dissertation).

[8] Davenport, M. \& Eib, B. J. (2004). Linking home and school with technology. Principal Leadership (High School Ed), 4(9), 54-56.

[9] Davies, D., Henderson, A. T., Johnson, V., \& Mapp, K. L. (2007). Beyond the bake sale: The essential guide to family-school partnerships. New York, NY: The New Press. https:// doi.org/10.1080/15582159.2012.702045

[10] Desforges, C., \& Abouchaar, A. (2003), The impact of parental involvement, parental support and family education on pupil achievements and adjustment: A literature review. London, UK: Department for Education and Skills 
[11] El Stohy, R. A. S, Khamessy, N., el Gharib. (2016), A Proposed System for Push Messaging on Android, International Journal of Interactive Mobile Technology (iJIM), Vol 10, No 3. https://doi.org/10.3991/ijim.v10i3.5567

[12] Epstein, J. (2001) School, family and community partnerships: preparing educators and improving schools, Boulder, CO: Westview Press. https://doi.org/10.4324/9780429493133

[13] Faridah, A.B., Naimah, I., Hamidah, Y., and Habibah, A.R. (2005). Poverty Education: Changes Mind of Malays Towards Academic Excellence in Education. Retrieved March 25, 2017 from: http://myais.fsktm.um.edu.my/2595/1/J_Peny_Pen.pdf

[14] Feenberg, A. (2005). Critical theory of Technology: An overview. Tailoring Biotechnologies, 1(1), 47-64. Retrieved from: http://www.sfu.ca/ andrewf/books/critbio.pdf

[15] Ferrara, M. M. (2009). Broadening the myopic vision of parent involvement. The School Community Journal, 19(2), 123-142.

[16] Feuerstein, A. (2000). School characteristics and Parent Involvement: Influences on participation in children's schools. The Journal of Educational Research, 94(1), 29-39. https:// doi.org/10.1080/00220670009598740

[17] Furger, R. (2006). Secret weapon discovered! Scientists say parents partnering with teachers can change the future of education. The Edutopian, 11, 46-49. (ERIC Document Reproduction Service No, ED346082).

[18] Ginsburg-Block, M., Manz, P. H., \& McWayne, C. (2010). Partnering to foster achievement in reading and mathematics. In S. Christenson, \& A. Reschly (Eds.), Handbook of school-family partnerships (pp. 175-203). New York.

[19] Graham-Clay, S. (2005). Communication with parents: Strategies for teachers. The School Community Journal, 16, 117-129.

[20] Hargittai, E. (2008). Whose space? Differences among users and non-users of social network sites. Journal of Computer-Mediated Communication, 13(1), 276-297. https://doi. org/10.1111/j.1083-6101.2007.00396.x

[21] Henrich, C., \& Gadaire, D. (2008). Head start and parental involvement. Infants and Young Children, 21, 56-69. https://doi.org/10.1097/01.iyc.0000306373.48038.e6

[22] Hoover-Dempsey, K. V. \& Sandler, H. M. (2005). The social context of parent involvement: A path to enhanced achievement. Nashville, TN. Vanderbilt University.

[23] Horrigan, J. (2008). Mobile access to data and information. Retrieved June 2015 from: http://www.pewInternet.org/Reports/2008/Mobile-Access-to-Data-and-Information.aspx

[24] Houtenville, A. J., \& Conway, K. S. (2008). Parental effort, school resources, and student achievement. Journal of Human Resources, XLIII (2), 437-453. https://doi.org/10.3368/jhr. $\underline{43.2 .437}$

[25] Jacobson, L. (2005). E-mail opens lines of communications for teachers. Education Week, 24(30), 8.

[26] Jeynes, W. (2007). The relationship between parental involvement and urban secondary school student academic achievement, a meta-analysis. Urban Education, 42, 82-110. https://doi.org/10.1177/0042085906293818

[27] Johnson, D. (2000). Techno-parenting. Library Talk, 13(2), 64.

[28] Li, L., \& Pitts, J. (2009). Does it really matter? Using virtual office hours to enhance student faculty interaction. Journal of Information Systems Education, 20(2), 175-185. Retrieved from: http://jise.org/

[29] Lunts, E. (2003). Parental involvement in children's education: Connecting family and school by using telecommunication technologies. Meridian: A Middle School Computer Technologies Journal. Retrieved June 22, 2017, from http://www.ncsu.edu/meridian /win2003/involvement/index.html 
[30] Marchant, M, \& Womack, S. (2010). Book in a bag. Blending social skills and academics. Teaching Exceptional Children, 42 (4), 6-12. https://doi.org/10.1177/004005991004200 $\underline{401}$

[31] McMillan, J. H., \& Schumacher, S. (2006). Research in education: Evidence-based Inquiry (6 ed.): Pearson Education Inc.

[32] Sheldon, S. B. (2009). In School, family, and community partnerships: Your handbook for action (3rd ed.). USA: Corwin Press.

[33] Stewart, E. (2008). School structural characteristics, student effort, peer associations and parental involvement: The influence of school-and individual-level factors on academic achievement. Education and Urban Society, 40(2), 179-204. https://doi.org/10.1177/00 13124507304167

[34] Tran, Y. (2014). Addressing reciprocity between families and schools: Why these bridges are instrumental for students' academic success. Improving Schools, 17 (1), 18-29. https://doi.org/10.1177/1365480213515296

[35] Urista, M. A., Dong, Q., \& Day, K. D. (2009). Explaining why young adults use MySpace and Facebook through uses and gratifications theory. Human Communication, 12(2), 215229. Retrieved July 2015 from http://onlinelibrary.wiley.com/journal /10.1111/\%28ISSN\%291468-2958

[36] Wei, R. (2008). Motivations for using the mobile phone for mass communications and entertainment. Telematics \& Informatics, 25(1), 36-47. https://doi.org/10.1016/j.tele.2006.03. $\underline{001}$

[37] Whitehead, B. (2000). How does technology measure up? Principal, 80(2), 45-46.

\section{$7 \quad$ Authors}

Azidah Abu Ziden is a Senior Lecturer in the School of Educational Studies, Universiti Sains Malaysia (USM). She is also the Deputy Director for the Centre for Development of Academic Excellent (CDAE), USM. Her research interest Her research interests are in the area of Instructional Design (E-learning \& M-learning), Educational Technology, ICT \& Multimedia and 21st Century Learning.

Muhammad Faizal Abdul Rahman works in the Hospital Seberang Jaya, Penang, Malaysia.

Too Woon Ching is a Master of Education graduate from School of Educational Studies, Universiti Sains Malaysia and currently is a teacher in a Secondary school in Penang, Malaysia.

Article submitted 2019-11-17. Resubmitted 2019-12-14. Final acceptance 2019-12-14. Final version published as submitted by the authors. 